\title{
Women in social work: Practice, policy and research
}

This issue of Aotearoa New Zealand Social Work begins with a special section of articles on the theme of women in social work. A second selection of articles with this focus will appear in a special section in the first issue of 2019.

Stephanie Wahab, Ben Anderson-Nathe, and Christina Gringeri write, in the introduction to Feminisms in Social Work Research (2015, p. 1), that "social work as a profession and academic discipline has long concerned itself with women and issues related to women and their social conditions" citing reproductive rights, labour rights, violence and poverty among the areas of concern. In 2018, women in Aotearoa and elsewhere still face challenges to reproductive rights, disadvantage in work and income, experience of violence and sexual harassment while Māori, Pasifika and other Indigenous women experience significant health disparities. Women are disproportionately high users of social services. They also provide a significant portion of care in their families and communities.

Gendered inequities also impact in the world of work. Women in social work are particularly affected by lack of equal pay for work of equal value while many enter professional social work with personal experiences of violence, trauma and poverty. Women also outnumber men in social work education and in the world of academia bringing with them the impacts of inequality in income, esteem and disproportionate caring responsibilities.

Social work is a profession in which women disproportionately contribute, and the concerns of women are often at the heart of social work practice-yet explicitly feminist writing has been relatively scarce in the Aotearoa New Zealand social work literature. Many commonly used Australasian social work texts do not include chapters on feminist practice. Feminist theory and practice is never far from my mind, my first published research article (Beddoe \& Weaver, 1988) examined the counselling services provides under the 1977 Contraception, Sterilisation and Abortion Act. When writing a lecture recently I searched for new material and found one recent Australian book: Contemporary Feminisms in Social Work Practice. The editors note in their introduction that, while there is a wide acceptance of women's right to equality, in abstract terms the lived reality of women's experiences is not so rosy. In both professional and personal life, social practices "continue to be framed by unspoken, even unconscious, discourses about women, their rights and their responsibilities, as qualitatively different from those of men" (Wendt \& Moulding, 2016, p. 2).

These discourses surface in the treatment of rape and intimate partner abuse, in double standards in sexual life, in workbased discrimination, pay inequality and in community and workplace sexual harassment and violence. A view of women's rights as less important than men's rights is implicit in the denial of safe, legal abortion healthcare and the increasingly draconian attempts to push back reproductive justice seen in the current climate of misogynist populism.

The articles in this special issue address some of these issues and are hopefully the starting point for some renewed enthusiasm for feminist writing about social work in Aotearoa New Zealand. An invited commentary, "Feminism and social work: Where next for an engaged theory
AOTEAROA

NEW ZEALAND SOCIAL WORK 30(3), 1-3. 
and practice?", by Viviene Cree, from the University of Edinburgh, in Scotland provides a personal view of how feminism has shaped aspects of practice. Professor Cree, whose research includes feminism in social work education, asks the question: "is the decision to lay claim to feminism (or not) purely a matter of individual choice, or is there something about social work that is, or should be, fundamentally feminist?" This commentary interrogates these questions more fully, drawing from research on feminism and the lived experience of "living and breathing feminism".

Social work education is the focus of the first article in the special section. In "Creating space for a critical feminist social work pedagogy", Sarah Epstein, Norah Hosken, and Sevi Vassos explore the challenges faced by feminist educators within contemporary universities. Drawing on literature the authors examine the processes that might develop to co-create a critical feminist pedagogical practice.

Social work research post-disaster offers new insights on the roles women take in community recovery. In "Mothers as active contributors to post-earthquake recovery in Christchurch", Angelina Jennings, Nicky Stanley Clark, and Polly Yeung report on a study of the post-disaster experiences of mothers from the two Christchurch earthquakes in 2010 and 2011. The article reports on the factors which both helped and hindered mothers' recovery. Resilience, a constructive and proactive role in their community post-disaster and a sense of belonging were found to be key to postdisaster recovery.

Reproductive health and the right to reproductive justice is an important aspect of feminist social work. A significant aspect of reproductive rights is found in access to safe legal abortion (Averitt Taylor, 2014). Abortion services are delivered within a complex system which is shaped by various philosophical, political and economic discourses. In an example of practice-near research, Shelley Kirk and her supervisors, Liz Beddoe and Shirley Ann Chinnery, report on a study of termination of pregnancy service delivery in Aotearoa New Zealand. This research is very topical given the current proposals for abortion law reform being considered (Law Commission, 2018). This article reports on a mixed methods study of aspects of the counselling service for women seeking a termination of pregnancy. Recommendations are made for service changes to improve patient-centred care.

Many of the challenges that confront contemporary social workers today are not new-over the past century, social workers have addressed poverty, unemployment, threats to peace and the challenges of refugee resettlement. It is useful to revisit our history of women activists in social work. Therese Jennissen and Colleen Lundy, in "Radical women in social work: A historical perspective from North America", explore the issues faced and strategies employed by five radical female social workers. These social workers were explicitly interested in social change that centred on social justice, women's rights, anti-racism, international peace, and they worked closely alongside other progressive groups.

In a viewpoint article, "Family Violencethrough the lens of reflective practice", Amitha Krishnamurthi shares a practice reflection. Utilising a case study and her own reflections, she explores family violence work and, in particular, the phenomenon of victim blaming which, she contends, operates as a defence against institutional anxieties. Krishnamurthi explores this work through her personal lens as a migrant woman from the Global South.

In this issue's Classic Book Review, Michele Jarldorn reviews Kris Olsson's “Kilroy was here". Jarldorn writes that this biography of an Australian woman, Debbie Kilroy, a former prisoner who survived the system and who is now a passionate advocate for prison reform. Jarldorn feels this book 
helped her consolidate the connections between theory, practice and experience.

Wendt and Moulding (2017) argue that feminism provides social workers with a sophisticated knowledge base from which to launch efforts for rights and recognition. As battles are being fought for adequate reproductive health care and freedom from abuse and violence, I must agree that "feminism has perhaps never been so relevant and necessary as it is right now" (Wendt \& Moulding, 2017, p. 262).

We will continue to explore the themes developed in this issue, in part two of this special issue to be published in 2019. The editors of Aotearoa New Zealand Social Work would be very pleased to receive more submissions on the concerns of women in social work, in particular policy and practice research of importance to Māori and Pasifika women, to migrants and resettled asylum seekers.

\section{General section}

In "Surveys, social licence and the Integrated Data Infrastructure" Pauline Gulliver, Monique Jonas, Tracey McIntosh, Janet Fanslow, and Debbie Waayer examine the social licence for including survey data in Statistics New Zealand's Integrated Data Infrastructure (IDI) which is a central repository for researchers to access multiple government agency data. The authors recruited two convenience samples: first, participants in one of 10 focus groups; and second, respondents to pilot surveys for the 2018 Aotearoa New Zealand census or a population-based survey on violence experience. Whilst little prior awareness of the IDI existed, participants identified concerns and suggested safeguards that would address concerns. In particular, the authors note that active engagement with Māori is essential given the overrepresentation of Māori within government agency data, to reduce risks of further stigmatisation and marginalisation.
Steve Rogowski's article, "Neoliberalism and social work with children and families in the UK: On-going challenges and critical possibilities", discusses how the welfare state has gradually been dismantled and become more punitive and market driven, and on the way social work has been "deprofessionalised and transformed into a narrower, more restricted, role" at the expense of relationship-based practice. Rogowski, a former children's social worker, argues that critical practice is ever more necessary and provides examples of what this might encompass.

\section{Liz Beddoe}

\section{References}

Averitt Taylor, J. (2014). Reproductive health policy affecting low-income women: Historical precedents and current need for social work action. Social Work in Public Health, 29(2), 132-140. doi:10.1080/19371918.2013.775872

Beddoe, L., \& Weaver, A. (1988). Ten years on: Abortion counselling services in New Zealand. New Zealand Social Work, 12(3/4), 23-28.

Law Commission. (2018). Alternative approaches to abortion law: Ministerial briefing paper. October 262018. Wellington, New Zealand: Author. Retrieved from https://www.lawcom.govt.nz/abortion

Wahab, S., Anderson-Nathe, B., Gringeri, C. E., Taylor, Francis, \& Gringeri, C. E. (2015). Feminisms in social work research: Promise and possibilities for justicebased knowledge. Abingdon, Oxon: Routledge.

Wendt, S., \& Moulding, N. (Eds.). (2016). Contemporary feminisms in social work practice. Abingdon, Oxon, UK: Routledge.

Wendt, S., \& Moulding, N. (2017). The current state of feminism and social work. Australian Social Work, 70(3), 261-262. doi:10.1080/0312407X.2017.1314752 